\title{
Using Games to Improve Students' Communicative Ability
}

\author{
Deguang Zhu \\ North China Institute of Science and Technology, Yanjiao, Beijing-east, China \\ Email: zhudeman@sina.com
}

\begin{abstract}
It is believed that the communicative language teaching approach (abbreviated as CLTA) is one of the most effective methods to keep away from the weaknesses of the traditional English teaching method in developing students' communicative ability. Using games, which is communicative in essence, are often considered effective in developing students' communicative ability. In order to help English teachers put the communicative language teaching approach into practice, this paper, on the basis of pointing out the weaknesses of the traditional English teaching method, discusses what the communicative language teaching approach is, states the value and importance of using games in English-teaching class, introduces eight types of games that could be used in class, and presents some suggestions when using the games.
\end{abstract}

Index Terms - communicative ability, games, suggestions

\section{INTRODUCTION}

Many have been said about the weaknesses of the traditional English teaching method in China, and the strengths of the communicative language teaching approach. However, the general situation of China's English teaching and learning at present is not very satisfactory, as "dumb English" is still stubbornly rooted in a large number of English learners. So it is safe to say that there is still a long way to go in English teaching reform and improving the English teaching quality of China. Sometimes it is easy to get a new method like the communicative language teaching approach heard but difficult to get it accepted, understood and applied to practical classroom teaching in the end. Therefore, it is not out of date to discuss the techniques of applying the communicative language teaching approach to classroom teaching. In this paper, the author, on the basis of pointing out the disadvantages of the traditional teaching method, discusses and explores one way to teach students effectively - using games in the English class, which is often considered as one of the best way to get the students involved in the classroom activities in which their communicative ability is practised and improved. Language games, as one of the most valuable and effective techniques in English language teaching, have been used for a long time by many western teachers. However, they are less used in China, especially in College English Teaching classrooms. Most teachers and students think games are a waste of time or just a fun activity for children. In this article, the author proposes to talk about the importance of using games in College English Teaching and list eight types of games to practise students' speaking and listening. Finally, some considerations are put forward on using games and the success of using games is stated.

\section{Traditional Teaching MethoD}

For years, the main method of teaching English in China is like this: firstly, the teacher explains the new words in the vocabulary list by giving definitions and examples. Then he/she will give a brief introduction to the background of the text. When dealing with the text, the teacher always explains and translates it sentence by sentence or even word by word, sometimes with a few questions which seldom elicit answers or responses from students. Finally, a reciting task or translation exercise is given to the students. In short, the traditional way of English teaching is teacher-centered and language-knowledge-focused. The way of teaching English is similar to that of teaching mathematics: new words presented, related grammar explained, and then written exercises assigned; if students can do the exercises well, it means that they have learned the language knowledge well, and then the lesson moves on. Under such pattern of teaching, students are passive information receiver and written exercises doer. They can remember large numbers of words and grammatical rules, and they can do very well in exams, but they scarcely have chances to express themselves in the target language and test their understanding of the received information about the language. And they are found having a lot of difficulty in communicating with others in English. This phenomenon is ironically defined as "Dumb English", which is the "product" of long hard work of both teachers and students.

\section{Communicative Language Teaching ApProach}

As the foreign language pedagogy has developed over the past few decades, we have experienced a number of methods and approaches to language teaching. Out of them the Communicative Language Teaching Approach (abbreviated as CLTA), at length, characterizes the present era. 
CLTA is best understood as an approach, not a method. It is based on the theory of the nature of language and of language learning and teaching. Language in nature is communicative for different purposes. It is a system for the expression of meaning. Its primary function is for interaction and communication. So the goal of language learning and teaching is to develop communicative competence. This communicative competence, in Canale and Swain's view (1980), includes grammar competence, sociolinguistic competence, discourse competence, and strategic competence. The acquisition of these competences, therefore, involves both cognitive and behavioral aspects, and the developments of the four basic skills at the same time. As we can see, this reasonable theoretical basis, perhaps, is just the reason why CLTA is attractive or popular.

CLTA emphasizes the importance of using authentic language. Language techniques are designed to engage learners in the pragmatic, authentic, functional use of language for meaningful purposes. So such communicative activities as authentic texts, scrambled sentences, language games, picture strip stories, role-play, should be used. Learners must be provided with ample opportunities to use the language themselves for communicative purposes. They are encouraged to deal with unrehearsed situations under the guidance of the teacher. The teacher's main tasks are to facilitate the communication process between the learners in the classroom and also to act as an independent learner within the learning-teaching group. The teacher should be, therefore, an organizer, a guide, a researcher, a needs analyst, a counselor, a group process manager, and a learner too, but not a controller. The instructional materials are text-based, task-based and realia. "Communicating to learn" and "learning to communicate" is the best description of CLTA.

CLTA, as a teaching approach, takes in all the new achievements in pedagogy, psychology and linguistics, so it is excellent in theory and beneficial to language learning and teaching. As for its operability, it is actually a matter of different variables according to different persons in different situations. CLTA is usually regarded as a guiding thought, which should be carried out in language learning and teaching activities. So how to put the guiding thought into practice becomes an ever-lasting topic for English teachers and researchers to work on, and the study of this topic can never be exhaustive.

\section{The VAlue And IMPORTANCE OF USING GAMES}

There are many good ideas about English teaching. Among these, using games in the English class is the one which is most easily accepted by students and which is also a very useful and helpful aspect of communicative method. As is known to everyone, game is an activity providing entertainment or amusement; it's a competitive activity or sport in which players contend with each other according to a set of rules. "A game is an activity carried out by co-operating or competing decision-makers, seeking to achieve, within a set of rules, their objectives" (Rixon 1981). A game is an activity that both the teacher and students enjoy doing. It is student-centered and as appealing as playing in the playground.

Using games in English class can get students relaxed and enjoying using the language. It may be argued that college students, unlike children, having grown up, do not need games to relax themselves. On the contrary, adults sometimes feel more nervous than children when they face new things, and they are more afraid of losing their face as the sense of face develops with their age. In this sense, they do need games or any other activity that help them relaxed and innocent like children to the new language without being afraid of making mistakes. According Stephen Krashen (1982), second language acquisition is influenced by affective factors either positively or negatively. One of the teacher's tasks is to create a situation where students' affective filter is lowered so that the comprehensible input could be taken in. The first aim of using games in class is just to create such a situation.

Games are communicative in essence, and so using game in English teaching and learning can well realize the fundamental idea of the communicative language teaching approach. Using games is a good way to improve students' various skills, as Wright, Betteridge and Buckby (2006) say, "Games can be found to give practice in all the skills, in all the stages of the teaching and learning and for many types of communication". In playing language games, students have to know and well understand the rules of the games, and should be clear about what has been, is being and will be done or said, and what is more important, they have to take some actions - doing or saying something, to compete in the games. In so doing, they can practise their skills of listening, speaking, reading and writing comprehensively, and especially they get more practice in listening and speaking, which are poor in the traditional teaching method. Littlewood (1981) proposed that through games, teachers should help learners go beyond the mastery of structures, to the point where they can use them to communicate meaning in real situations.

Game playing is effective in developing students' communicative ability in that it is a dynamic process of communication in which students as thinking beings, emotional beings and communicators instead of knowledge receptacles, try to get their ideas, concepts, thoughts, emotions and feelings expressed, based on their own life experiences. Psychologist Piaget (2001) proposes that movement produces "thought". He believes that movement is the beginning of learning, and that cognitive frame is built up step by step whose joint is the movement but not the consciousness.

In addition, games may help and encourage many learners to support their interest and work (Wright 2006). Games can increase motivation to learn the language as students, especially the weaker ones, feel a real sense of achievement when they manipulate a game (Hubbard 1987). Games can provide quite extensive knowledge input. Games can increase students' communication and co-operation with each other. And games can act as a testing mechanism through 
which they will expose areas of weakness and the need for remedial work.

Furthermore, games can be used at any stage in a lesson: at the beginning to diagnose what the students can or cannot do; during the lesson for language practice purposes; or at the end as reinforcement and 'reward'. Students playing language games are encouraged to express their ideas for certain purpose, and they can use different types of games at different stages appropriate for different types of language learning.

\section{TYPES OF GAMES}

As stated above, the main purpose of using games in English classes is to practise students' different skills, especially their communicative ability. Here, eight types of games from published sources (Carrier 1980, Ellis 1986, Harmer 1985, Kallsen 1982, Klippel 1984, MaCallum 1980, Porter-Ladousse 1987, Stern 2002, Willis 1982, etc.) are identified, discussed and explored.

\section{A. Guessing Games}

The basic role of guessing games is very simple: one person knows something that another one wants to find out. The thing to be guessed can differ greatly from game to game. It can be a word, an object, an activity or many other things. Guessing games are useful in helping students practise logical thinking and asking questions. 3 -item story is one example of a guessing game. One person in a group knows the story in which there are three items given to the other members of the group. Depending on the three items, they have to ask questions to find the story. The person who holds the story can only give yes or no answers. The guessing members have to use their questioning skills to get the answer. To give an example of pun: the teacher gives the students a question to explain: "Why do they tie a horse to a post before a race?" The students have to widen their thinking instead of being occupied in a narrow way and be told to think of more than one sense of a word or a sentence. Then after a period of thinking, they are likely to find the answer: "Because they want to make the horse fast." Here, fast has two meaning which can be firmly fixed or quick.

\section{B. Picture Games}

Picture games include several types:

Comparing and contrasting pictures;

Considering differences or similarities;

Considering possible relationships between pictures, such as narrative sequence;

Describing key features so that someone else may identify them or represent them in a similar way;

Making a story according to the given picture.

Most of these picture games involve the learners in the relatively free use of all the language at their command and at the same time give them the opportunity to practise their speaking and listening.

\section{Sound Games}

Sound effects can create in the listeners' mind an impression of people, places and actions. There is a demand for the listener to contribute through the imagination. This inevitably leads to individual interpretations which mean that the listeners can exchange their points of view and express opinions and ideas. This kind of games can stimulate students' imagination and thinking, and offer them a chance to practise their listening and speaking. Students can make guess at the object described by sound, or make dialogue or a story.

\section{Mime}

Mimes can be done in pairs, groups or even by the whole class. One side has to perform the mimes for the other side so that the answer can be found. It can be an object, action or person. So miming activities are valuable language-learning situations. Guessing something is linked with the real desire to find out and thus is a true communication situation. Miming trains the students' skill of observation and improvisation. It emphasizes the importance of gesture and facial expression in communication. For example:

A guest in a hotel in an English-speaking country has a very bad cold and has lost his voice. He wants the receptionist to help him turn on the heating. But he has to mime because of his voice. He tries to make the receptionist understand him by using gestures and expressions. The receptionist makes guesses by asking questions in order to find out what he wants. The activity will not stop until the receptionist gets exactly what the guest wants to do. This game can be done in pairs or in groups.

\section{E. Fact-finding Games}

This mainly deals with general knowledge and is a very practical exercise. Everyday, there is something important happening, so the students can be asked what happened on a day in history. It may be a historical accident, a birthday of a famous person, or something strange or marvelous. Then further details can be asked. The students can discuss in pairs or groups in order to find much more information.

If the students have a class on 16 April, the teacher can ask the students to do the following activity. Let the students sit in groups. Ask the question, 'Do you know who the main actor in the films 'Modern Times', 'The Gold Rush' and 'The Great Dictator' is?' The students are sure to name Chaplin, because the films are very famous. Then the teacher 
tells the students that that day is his birthday and that it is necessary for the students to know something about him. After that, more work can be done by drawing a typical picture of him and describing his appearance. At last, the teacher can ask the students to think why Chaplin is loved by people all over the world and why his films are so popular. Now the students have had a chance to really think about what they know about the person.

\section{F. Debates}

In this activity, a topic is given and two sides are set up, one supporting the idea and the other opposing it. Then they argue giving their evidence. The aim of this activity is to get the students to talk and stimulate their interest and competitive spirit. Such activities make the students think about their values and priorities. There is no doubt that this activity will improve students' conversation and eloquence.

\section{G. Jigsaw Games}

Each participant in a jigsaw task holds one part of a solution, which may be a story, a factual text or a picture. They are equally important. They should work together to fit their pieces together to find the solution. They, therefore, improve co-operation and mutual acceptance within the group. Participants in this game have to do a lot of talking before they are able to fit the pieces together in the right way. Wright (2006) also claims that these games practise two very different areas of skill in the foreign language: "Firstly, the students have to understand the bits of information they are given and describe them to the rest of the group." This helps them realize the importance of pronunciation and intonation in making oneself understood. "Secondly, the students have to organize the process of finding the solution and a lot of interactional language is needed."

\section{H. Role Plays}

Role plays often consist of short scenes, which can be realistic or pure fantasy. Role plays may be enacted around everyday situations as well as around topical problems. One easily-obtained role play is from the text, which may be actual role play material. After learning the text, students can be asked to give a performance of it. This can improve their oral performance generally and, of course, help students to understand what they have learned in an easy way. Furthermore, role plays are useful for generating free expression and the feeling of spontaneity in the language classroom.

\section{SugGestions ON USING GAMES}

There are four elements which should be taken into consideration when playing games in English class. Teachers should keep them in mind and apply the above discussed games to the practical situation appropriately in order to achieve the best results.

\section{A. Time}

The amount of teaching time devoted to games depends on the individual teaching content, but it will probably be a relatively small proportion of the total teaching time. They can be used to open or close a lesson in a stimulation way, to punctuate a lesson, to relieve tension after a test or concentrated practice session, or at any time that the teacher feels appropriate. It is important that they are used positively, to give students enjoyment and useful practice.

\section{B. Choice}

In each category of game mentioned above, there are different kinds of games. So the teacher must take many factors into account when deciding which game would be most appropriate and most successful with his or her students at any time. He or she should consider the level of the students, the main aim of having a game, the interest of the students, the appropriate time to use a game and the availability of aids and materials.

\section{Preparation}

Games may be good fun but they need to be carefully prepared and organized. Firstly, the teacher should find a good game in a book or invent one. Then he or she must be sure that the necessary facilities are available. An overhead projector can be very useful if one is available. If not, a typewriter and cards and the objects needed should be prepared in advance. Also, the teacher should ensure clear handwriting on paper or cards so that the students will take the teacher's intentions seriously. Finally, the teacher must work out how the game is to proceed, what the students will need to do and how they will be instructed in what to do. It is important to try to anticipate any logistic or linguistic problems that may occur in order to be able to deal with them effectively.

\section{Management}

The teacher must decide in advance how to organize the students and the classroom so that the setting up of a game can be carried out as quickly and smoothly as possible. It is advisable to encourage pair and group work where possible, as this will increase student participation and the amount of language practice offered to each student will be much greater. While the students are working, it is useful for the teacher to keep a close eye on pairs or groups to help, correct or stimulate less active students. The teacher should stop a game and change to something else before the students 
become tired of it. In this way, their willingness and concentration are retained.

\section{CONCLUSION}

From the above analysis, a conclusion can be drawn that teaching and learning English by means of language games is effective and efficient in improving students' communicative ability. While in the traditional method of teaching English, students sit still listening to teachers talking about English language and try their best to remember English words and grammatical rules by rote memory, in the communicative language teaching approach they are actively involved in playing games which in turn can arouse and maintain their interest in learning, promote their motivation of study, and at the same time get lots of opportunities to have their basic skills of listening and speaking practiced. Admittedly, there are many difficulties in using games in most English classes, but it is possible to use them as long as both teachers and students appreciate their value and function. When using games, such factors as the time, choice, preparation and management should be put into consideration, which is the guarantee of successful use of language games in class. In a word, using games in English teaching very well represents the theme of the communicative language teaching approach - "Communicating to learn" and "learning to communicate".

\section{REFERENCES}

[1] Canale, M., M. Swain. (1980). Theoretical bases of communicative approaches to second language teaching and testing. Applied Linguistics, 1, 1-47.

[2] Carrier, Michael. (1980). Take 5 Games and Activities for the Language Learner. Edinburgh: Nelson 's Company.

[3] Ellis, Rod. (1986). Understanding Second Language Acquisition. Oxford: Oxford University Press.

[4] Harmer, J. (1985). The Practice of English Language Teaching. New York: Longman.

[5] Hubbard, J. (1987). A Training Course for ELT. Oxford: Oxford University Press.

[6] Kallsen, Loren J. (1987). Advanced Communication Games. Edinburgh: Nelson's Company.

[7] Klippel, Fredric. (1984). Keep Talking. Cambridge: Cambridge University Press.

[8] Krashen, S. (1982). Principles and Practice in Second Language Acquisition. Oxford: Pergamon.

[9] Littlewood, William. (1981). Communicative Language Teaching. Cambridge: Cambridge University Press.

[10] MaCallum, G. P. (1980). 101 Word Games. Oxford: Oxford University Press.

[11] Piaget, Jean. (2001). The Language and Thought of the Children. London: Routledge.

[12] Porter-Ladousse, G. (1987). Role Play. Oxford: Oxford University Press.

[13] Rixon, Steven. (1981). How to Use Games in Language Teaching. London: Macmillan.

[14] Stern, H.H. (2002). Fundamental Concepts of Language Teaching. Shanghai: Shanghai Foreign Language Education Press.

[15] Wright, A., D. Betteridge, M. Buckby. (2006). Games for Language Learning ( $3^{\text {rd }}$ edn.). Cambridge: Cambridge University Press.

[16] Willis, J. (1982). Teaching English Through English: A Course in Classroom Language and Techniques (Handbooks for Language Teachers). London: Longman.

Deguang Zhu was born in Guyuan County, Hebei Province, China in 1967. He received his M.A. degree in foreign linguistics and applied linguistics from Beijing University of Aeronautics and Astronautics, China in 2002.

$\mathrm{He}$ is currently an associate professor in the School of Foreign Languages, North China Institute of Science and Technology, Yanjiao, Beijing East, China. His research interests include linguistics, second language acquisition and foreign language teaching methodology. 